\title{
The Re-Emerging Role of the State in Contemporary Russia
}

Nadia Vanteeva, University of Oxford 


\title{
The Re-Emerging Role of the State in Contemporary Russia
}

\begin{abstract}
I examine ownership structure of Russian firms during the 1998-2006 period, where a greater emphasis is placed on motivations behind increased government ownership in the latter years, when oligarchs' opportunistic influence on the firm diminished as state ownership in companies correspondingly increased. As this phenomenon is also consistent with improved corporate growth during the period, I argue that state reintervention acted as an effective substitute governing mechanism to constrain wealthtunnelling behaviour of corporate insiders and local bureaucrats in a country defined by a weak property rights system.
\end{abstract}

JEL Codes: G32, P26, P27

Key words: State co-ownership, corporate governance, Russia

\section{Introduction}

Russia is an important example of an economic system having ill-defined property rights, persistently lacking a contractual mechanism acting to enhance its commercial development. This is particularly significant in the post Soviet regime, when the nation has distanced itself from state-mandated output and investment targets by freeing-up markets and allowing a market-clearing prices allocation system to evolve. A key aspect of Yeltsin's "privatisation" initiative was the freeing-up of commercial and industrial 
enterprises from direct state control by allowing major corporations to become privately owned through a mechanism of management buyouts and issuance of vouchers and shares. The objective of the programme was to enable private economic agents to decide on the optimal level of production and investment, which should lead to an improved firm performance.

However, as is generally accepted, such reforms led to a severe economic contraction because of the absence of a well-defined and enforceable property rights system, which is necessary for the emergence of efficient market institutions. The absence of the latter facilitated the ability of various ruling elite groups, such as the new business quasi-owners and local bureaucrats to engage in extensive asset-stripping. For instance, the managers of Soviet enterprises were able to attain large ownership stakes in the newly-privatised companies at subsidised rates due to their superior knowledge of the Soviet bribing system, which prospered during the Yeltsin era (Shleifer and Vishny, 1998). Managerial ownership became concentrated, and the new "owners" seized assets and subsequently sold them to their own private businesses (Rapaczynski, 1996; Alexeev, 1999; Black et al., 2000; Sonin, 2000; Kuznetsov and Muravyev, 2001).

The "loans for shares" scheme is often referred to as the most scandalous in the history of privatisation (Hedlund, 2001). Banks and other financial institutions provided government with loans in exchange for shares, which were treated as collateral in the case of government's default on repayment of debt. Unsurprisingly, the auctions for such shares were held in a non-transparent way, where banks with close political ties to the government obtained the top bidding position (Appel, 1997). After the government had defaulted on its debt, the auctions for shares took place, and these were held in such a 
way as to restrict the number of bidders in order to keep share prices artificially low. As a result, shares of Russia's most desirable firms were placed with a very small number of banks for significantly less than they were worth (Dyck, 2002; Puffer and McCarthy, 2003). In turn, such banks colluded in wealth redistribution, as they reallocated resources to favoured industries and individuals instead of acting as intermediaries between borrowers and lenders (Thomson, 2002; Spicer and Pyle, 2003). Local and regional government officials also managed to gain control over many corporations (Guriev and Rachinsky, 2005) and used their increased power to pursue wealth tunnelling agenda.

In short, it can be argued that the new class of quasi-owners was unsure about its future income claims, hence it chose to adopt shorter investment horizons than the social optimum, which led to asset-stripping, corresponding fall in production and extensive capital flight (Stiglitz, 2002; Hoff and Stiglitz, 2004; Ross, 2004). Stiglitz (2002) believes that as privatisation occurred without the essential prerequisites, such as a well-defined property rights system, it did not offer incentives for effective private ownership - instead it offered an incentive to "grab" the resources and engage in the tunnelling of wealth.

Consequently, following a period of economic stagnation, the Putin regime reintroduced an active role of the state in the economy in order to constrain wealth diversion by corporate insiders and local bureaucrats. Significantly, although it can be said that at present many Russian corporations can be defined by ownership and corporate governance characteristics of Western corporations, there is also an important difference in that the central state often has a major ownership stake as well as corporate governance presence in the firm. While a strong property rights system still remains Russia's long-term goal, the new partnership between the central state and private 
investors may have acted as an effective substitute to constrain wealth tunnelling behaviour, as is demonstrated by improved performance of Russian corporations during the Putin regime.

The remainder of this paper is structured as follows. Section 2 examines literature which focuses on immediate post privatisation corporate ownership trends as well the reemerging role of the central state with the advent of the Putin regime. Section 3 provides detailed ownership data on firms which traded on the Russian Trading System stock exchange (RTS) over the 1998-2006 period, signalling that the central state did indeed become a corporate co-partner in firms defined by high hold-up costs. The section also presents a rationale for the federal government's role in firm ownership structure and its corporate governance. Finally, Section 4 offers further discussion and conclusion.

\section{Corporate ownership in Russia}

\subsection{Post privatisation ownership trends}

Hoffman (2002) characterised the first decade of Russia's leap towards the free market as one plagued by insider dealings, theft and widespread masked money flows. It is, therefore, unsurprising that consistent and reliable information about the new owners does not exist. Most of corporate ownership literature focuses on survey data, as official company reports fail to identify ultimate owners, who chose to remain anonymous in order to conceal their wealth tunnelling behaviour. Nevertheless, the existing studies provide strong evidence that Yeltsin's privatisation initiative failed to create a pool of outside investors, which Boycko et al. (1995) hoped would be free of political ties and interference. While by the end of mass privatisation period 77.2 percent of large and 
medium size firms were acquired by private owners, which corresponded to 88.3 percent of Russia's industrial output (Debardeleben, 1999), 70 percent of privatised firms were associated with insider ownership (Frydman et al., 1999).

For example, Filatotchev et al. (1999) use a sample of over 300 firms in Russia over the 1995-1996 period to illustrate that managers extensively accumulated firm shares and colluded with firm employees in order to entrench insider control and exclude outsider investors. Sprenger (2002) notes that outside shareholder rights were disregarded by self-dealing management, when the latter engaged in asset-stripping, transfer pricing and share dilution.

Furthermore, the Yeltsin regime was also associated with the decreased power of the central state and a corresponding increased power of regional bureaucrats (Robinson, 2002). The new decentralisation policies accommodated local and regional government officials in diverting corporate control, which was then used for their personal enrichment goals (Coffee, 1999; Fox and Heller, 2000).

The period also saw the emergence of Financial-Industrial Groups (FIGs). These consisted of a combination of banks and industrial enterprises, which were often characterised by cross-ownership based on personal ties. Many FIGs were a result of the loans for shares scheme, having significant political power to assist their insider dealings. Notably, while Perotti and Gelfer (2001) find a negative relationship between cash flows and investment in FIGs, consistent with the reallocation of resources and perhaps a more effective financial reallocation, they could not rule out the stripping of assets from more profitable enterprises by insiders. 
In summary, it is often posited that Russia's privatisation process was an incredible failure. Corporate insiders and local bureaucrats have amassed most of minority shareholders' stakes, and ownership and control of Russian corporations was defined by highly concentrated ownership structures, where oligarch quasi-owners engaged in extensive self-dealing (Black, 1998) in an environment characterised by a weak legal system. Unsurprisingly, new enterprises failed to emerge, Russia was unsuccessful in attracting foreign investment capital and the objective of maximising the long-term corporate growth proved illusive.

\subsection{The re-emergence of the state under the Putin regime}

As previously discussed, the initial period of Russian commercial restructuring was typically deemed as unsuccessful and it is widely believed that in large part this was due to the absence of a legal system, which has been incapable of imposing well-defined property rights. However, in contrast to the earlier period, the Russian economy registered a significant GDP growth (of 8 percent) in 2000, followed by similar growth patterns in the subsequent years. For the first time since the Yeltsin regime, the country had witnessed increased levels of domestic and foreign investment. Moreover, despite the lack of an effective legal system during the period Russian corporations thrived. Figure 1 below displays the improved performance of the Russian corporate sector, as is exhibited by the Russian Trading System stock exchange index during the period.

[insert Figure 1 here] 
It is generally recognised that Russia's fast economic recovery can in large part be attributed to the rise in world oil and gas prices, where the abundance of natural resources has undoubtedly contributed to Russia's economic fortune. However, in this paper I suggest that the reforms introduced under the Putin regime also played a significant, if not a dominant role in Russia's dramatically improved performance over the period. These reforms acted as the second best strategy to enhance economic growth in the absence of a well-defined property rights system.

The new regime ushered under Putin concentrated on re-introducing the state as a major player in the Russian economy. The influence of the oligarchs was significantly diminished, especially in the political sector (Goldman, 2003; Tompson, 2005), while asset-stripping behaviour was also dramatically reduced. The federal government curbed regional bureaucracy by adopting the "vertical flow of power" approach and transferring the decision-making power back to the central state (Gregory and Schrettl, 2004; Bahry, 2005; Dininio and Orttung, 2005; Ivanenko, 2005).

Interestingly, the new policy was still a somewhat free market approach in that all prices and output quantities, except that in a few strategic industries, were allowed to be determined by the market. ${ }^{i}$ However, an important aspect of the Putin regime was that the state re-engaged directly with Russia's main industries. It openly regained control over Russia's most strategic economic sectors, such as energy (Boussena and Locatelli, 2005; Goldman, 2008; Kalyuzhnova and Nygaard, 2008; Hanson 2009; Rossiaud and Locatelli, 2009). However, as Tompson (2008) points out, although the state did concentrate on increasing its stake in oil enterprises, it did not specifically target Russia's natural resource industry alone, but instead acquired shares in a wide variety of economic 
sectors. Woodruff (2007) notes that Russia's state-owned stock accounted for 20 percent of market capitalisation in 2003, a figure which rose to 35 percent in 2007.

Significantly, while many (for e.g. Smith, 2009; Vidova, 2009) suggest that Russia under the Putin regime was steering a steady course through the re-nationalisation of enterprises, I argue that the government, above all, pursued the co-ownership policy, where it formed co-partnerships with private investors in many important industries. In other words, the co-partnership is a product of a complete state ownership of corporations as in the old Soviet Union, and the disastrous "laissez-faire" system, which existed during the Yeltsin era, but was carried out with incomplete claims over assets. I believe that such co-partnership system was formed in response to severe hold-up costs generated by weak property rights. In other words, the new regime recognised the necessity of becoming an active corporate partner with private investors to ameliorate costs associated with substantial hold-up due to the propensity of oligarchs and local bureaucracy to divert wealth. Interestingly, Gaddy (2007) points out that the Putin regime did not necessary pursue re-nationalisation, but the central state effectively acts as a rent manager, having complete control over oil and gas rent sharing system. To put another way, the federal government does not differentiate between state and private ownership, as it successfully extracts formal and informal taxes from private firms. In this paper, it is argued that while the central state is undoubtedly in charge of this rent sharing system, it also favours the co-partnership mechanism. This mechanism allows the state to bypass the necessity to appoint "loyal agents in the right positions... to ensure that the rents are properly distributed" (Gaddy, 2007:42), as the state now has a major corporate governance presence, which ultimately translates into significant decision-making power; while also 
permitting the state to benefit from injection of private investment funds. Lane (2008) notes a striking increase of Western investment during the Putin period. From the investors' perspective, such state-private co-partnership system can act as a substitute governing mechanism to more assure private investors of their expected return, as the state cannot allow corporate insiders and lower level bureaucrats of the 1990s to engage in extensive tunnelling of wealth.

In the next section I provide a detailed study of ownership structure in Russia during the 1998-2006 period. I show that many firms in oil and other natural resource sectors, as well as manufacturing industry have adopted the state-private co-partnership system. I believe that by having a significant ownership stake in the firm the state can effectively constrain appropriation of private investment funds as well as large government subsidies by insiders.

\section{Corporate ownership in Russia}

The study is based on firms which trade on the Russian Trading System (RTS) stock exchange, which is one of Russia's leading stock exchanges, between 1998 and 2006. Russian Trading System stock exchange (RTS) serves as the main benchmark for the Russian securities industry. It is based on RTS 50 most liquid and capitalised shares. The firm sample consists of energy, metallurgy and mining, manufacturing, communications, banking and services, food and retail, transport and utility enterprises, which represents all major sectors of the Russian industry. At the time of data collection, 329 companies were listed on RTS stock exchange; however, due to the absence of information for 
ownership of several companies, the final sample was reduced to 245 . Table 1 below shows industrial composition of RTS index. ${ }^{\text {ii }}$

\section{[insert Table 1 here]}

I identify key shareholders (represented by the fraction of capital they own) from company annual or quarterly reports, which were provided by SKRIN database. In general, Russian corporate ownership can be described as highly concentrated, where the average fraction of capital held by the principal shareholder is approximately 50 percent. Therefore, even though the reports officially disclose all shareholders that own more than five percent of firm's capital, it is determined that all major owners hold a very significant share of capital. ${ }^{\mathrm{iii}}$ If the reports state that there is more than one principal investor present, all types of large shareholders with large ownership stakes were noted.

I identify the following owner types - federal government (direct state ownership), state firm or financial institution (indirect central state ownership), regional state (regional state ownership), domestic firm or financial institution (private ownership), individuals (private ownership), and finally, foreign firm and financial institution (foreign ownership). In order to provide a more general overview of Russian corporate ownership, direct and indirect central state ownership are grouped together, while separating this ownership category from regional state ownership, as the latter is being curbed under Putin administration. In addition, I note the presence of the new state-private copartnership system, or co-ownership between the central state and private investors, which was increasingly implemented with the advent of the Putin regime. Table 2 below 
summarises the number and type of owners present across Russia's corporate sector between 1998 and 2006, as is reported by companies trading on RTS.

[insert Table 2 here]

Direct or indirect state ownership represents the number of firms in which the federal government held a majority stake throughout the given period, or in other words, was the single key shareholder. Significant presence of the state shareholder can be attributed to a large number of electricity companies in the firm sample, which are the subsidiaries of the United Energy Systems of Russia (where the state is the largest investor), trading on the RTS. An increased number of directly or indirectly state-owned corporations in the latter period can be attributed to the restructuring of the United Energy Systems of Russia, where a number of new subsidiaries have emerged.

One must note a sharp decline in regional government investor type from 2003 onwards. These findings are consistent with the new policy of corporate control being transferred back to the federal government and limitation of decision-making power of regional officials, who previously enjoyed autonomy over corporate assets.

The findings show that the number of private investors, both domestic and foreign, also increased steadily throughout the period. This is unsurprising as Russia's rapid economic growth has attracted a large amount of private investment funds. However, it is important to point out that approximately 80 percent of this "private" corporate ownership structure is represented by two or more large shareholders (for example, the firm is owned by a foreign corporation and a domestic financial institution). 
Such combinations of shareholders account for a relatively high number of domestic and foreign participants in the table. iv Individual ownership has remained relatively low throughout the given period.

Significantly, it can be seen from the table that the new state-private co-ownership system, which captures firms that are co-owned by the central state and private investors, increased dramatically with the introduction of the Putin regime. This is consistent with the government's policy of regaining a certain degree of control over the Russian industry without pursuing the re-nationalisation objective. Moreover, as such copartnership mechanism can be found across energy sector (see Table 3), it is argued that the central state may have favoured this strategy over the strict "rent management" mechanism, which involves extensive monitoring of private owners by the state in order to collect a sufficient amount of economic rents. To put another way, through partial ownership the state can successfully amass energy sector rents in a less costly manner.

However, findings in Table 3 below show that the central state did not only seek to form co-partnerships in energy enterprises, but across all economic sectors that can be characterised by high asset specificity, large lump-sum investment outlays, and consequently, high hold-up costs. Specifically, the energy sector has increased its proportion of co-owned enterprises from $6 \%$ in 1998 to $16 \%$ in 2006 , while metallurgy and mining industry raised this share from $0 \%$ to $21 \%{ }^{\mathrm{v}}$ One notices a dramatic increase in the state-private co-partnership system across manufacturing firms (from 0\% in 1998 to $30 \%$ in 2006). Transport industry, which consists of airlines and shipping, saw the proportion of state-private co-ownership mechanism decrease from $29 \%$ to $14 \%$, however, this major change can be attributed to a small sample of firms in this economic 
sector (seven transport companies trading on RTS were identified). Finally, it can be seen that the utility sector, even though mainly controlled by the central state, also tended to adopt the co-partnership system, where the proportion of co-owned companies augmented from $2 \%$ in 1998 to $18 \%$ in 2006.

Significantly, it can be seen from the table that the proportion of co-owned enterprises across communications, banking and services and food and retail sectors (all of which are not defined by high asset specificity and large initial investment outlays) decreased steadily throughout the period. Banking and services industry expanded rapidly between 1998 and 2006, yet this economic sector did not introduce the co-partnership system, producing an overall effect of a decline in the co-ownership mechanism. Food and retail sector has also grown, but similar to banking and services industry, it did not aim to form a partnership between private investors and the state, thus resulting in a fall in co-owned enterprises from $20 \%$ in 1998 to $7 \%$ in 2006 . The share of the state-private co-partnership system remained low (7\%) relative to other forms of ownerships across communications industry.

[insert Table 3 here]

These findings are consistent with the argument that instead of pursuing the renationalisation objective, the central government introduced the new state-private copartnership system, which it expected to act as a second-best strategy to well-defined property rights. In that, the new regime recognised that the economy lacked an efficient property rights system, and it also recognised the necessity of becoming an active 
corporate partner with private investors (who could offer significant investment funds to the growing economy) to ameliorate costs associated with substantial hold-up due to the propensity of oligarchs and local bureaucracy to divert wealth. ${ }^{\text {vi }}$ The policy also implies that such co-partnership system plays a more dominant role across enterprises characterised by large lump-sum investments outlays and high asset specificity. These lead to higher hold-up costs stemming from extensive rent-seeking by company insiders and local bureaucrats, and thus call for enhanced monitoring by the state.

\section{Conclusion and discussion}

In this paper I argue that with the advent of the Putin regime in 2000, the Russian state did not essentially pursue the re-nationalisation goal, although it is widely recognised that the new government began to regain control over the Russian industry. Undoubtedly, having autonomy (through direct ownership or formal and informal taxes) over energy sector rents provided the federal government with much needed funds to start re-building Russia's industrial base and increasing the country's living standards. However, after studying ownership structure of firms listed on the Russian Trading Systems stock exchange during the 1998-2006 period, it can be seen that the government aspired to introduce a co-ownership system between the central state and private investors in all industries defined by high asset specificity and substantial investment outlays.

Contemporary Russia, consistent with its past, remains characterised by a weak property rights system, which impedes its commercial development. Despite being a recipient of significant economic rents, the government recognises the need to secure

private investment funds, which aid economic growth. ${ }^{\text {vii }}$ Thus it is the state's objective to 
adopt a mechanism, which can guarantee investors their expected return. This, I argue, can be accomplished through the state-private co-partnership. Without the co-partnership strategy, many projects face an under-investment trap. Specifically, there remains a potential conflict between the state and insider managers or local bureaucrats, who have a tendency to invest sub-optimally. As was demonstrated by Russia's privatisation initiative, irrespective of their time discount preferences, the insiders can be expected to adopt shorter term investment horizons, because they lack secure claims to future income. Thus, even if they sell their interest, the insecurity of the future assets income claims will appropriately be subject to a risk-adjusted discount rate, which may increase overtime. Subsequently, in this paper it is suggested that in the absence of well-defined property rights, private investment can be secured if the central state makes a credible commitment to investors to protect their funds from wealth diversion behaviour of company managers and lower level bureaucrats. This, in turn, can be achieved by giving the central state an active role in company governing structure through firm co-ownership, which is all the more important in firms with highly specific assets, requiring large investment outlays.

Naturally, one may address the issue of credible commitment to private investors by the state, i.e. how can investors be confident that the state itself will not turn into a predator. However, it can be argued that the state is only likely to display predatory behaviour when under threat - if it expects to receive fewer economic benefits in the next period. In this case, the government is already a major owner of Russia's resources, hence the level of threat is somewhat limited. Moreover, the state's long-term goal is to sponsor economic development with private investment funds in the absence of enforceable property rights, therefore it needs to assure investors of their expected 
returns. In the case of ex post contractual non-compliance, or investor expropriation, investors will choose to withdraw their funds (if possible) and refrain from future opportunities. Consequently, the state's aspiration to achieve long-term development will prove to be illusive. To put another way, if private investors' expected returns do not reflect a risk-adjusted competitive return due to non-commitment by the government (which may include the state's wealth tunnelling behaviour, its political agenda or any other forms of predatory behaviour), the government will not be able to secure private funds over the desired long-term period.

To summarise, I argue that given a poorly-defined property rights system in Russia, the state aspires to achieve long-run economic growth by introducing the new copartnership system between the state and private investors. This system can act as an effective substitute corporate governance mechanism, in that it can reduce significant hold-up costs stemming from rent-seeking behaviour of corporate insiders. It is also argued that the state is unlikely to find it profitable to engage in predatory behaviour, as private investors need to be assured of their expected returns in order to sponsor Russia's corporate growth. 


\section{References}

Alexeev, M. 1999. "The Effect of Privatisation on Wealth Distribution in Russia." Economics of Transition 7: 449-465.

Appel, H. 1997. "Voucher Privatization in Russia: Structural Consequences and Mass Response in the Second Period of Reform.” Europe-Asia Studies 49: 1433-1449.

Bahry, D. 2005. "The New Federalism and the Paradoxes of Regional Sovereignty in Russia." Comparative Politics 37: 127-146.

Black, B. 1998. "Shareholder Robbery, Russian Style." Institutional Shareholder Services, ISSue Alert: 3,14.

Black, B.S., Kraakman, R., and A.S. Tarassova. 2000. "Russian Privatisation and Corporate Governance: What Went Wrong?" Stanford Law Review 52: 1731-1808.

Boussena, S., and C. Locatelli. 2005. "The Bases of a New Organisation of the Russian Oil Sector: Between Private and State Ownership." Available at http://upmf-grenoble.fr/iepe/textes/SB-CL_bases_JlofEnergyandDev05.pdf

Boycko, M., Shleifer, A., and R.W. Vishny. 1995. Privatising Russia. Cambridge, MA: The MIT Press.

Coffee, J.C. 1999. "Privatization and Corporate Governance: the Lessons from Securities Market Failure." Journal of Corporate Law 25: 1-39.

Debardeleben, J. 1999. “Attitudes Towards Privatisation in Russia.” Europe-Asia Studies 51: 447-465.

Dininio, P., and R. Orttung. 2005. "Explaining Patterns of Corruption in the Russian Regions." World Politics 57: 500-529.

Dyck, A. 2002. "The Hermitage Fund: Media and Corporate Governance in Russia." Harvard Business School, Working Paper No. N2-703-010.

Filatotchev, I., Wright, M., and M. Bleaney. 1999. "Privatisation, Insider Control and Managerial Entrenchment in Russia.” Economics of Transition 7: 481-504.

Fox, M.B., and M.A. Heller. 2000. "Lessons From Fiascos in Russian Corporate Governance." University of Michigan Law School and William Davidson Institute, Working Paper No. 99-012.

Frydman, R., Gray, C.W., Hessel, M.P., and A. Rapaczynski. 1999. "When Does Privatisation Work? The Impact of Private Ownership on Corporate Performance in the Transition Economies.” The Quarterly Journal of Economics 114: 1153-1191. 
Gaddy, C.G. 2007. "The Russian Economy in the Year 2006." Post-Soviet Affairs 23: 3849.

Goldman, M.I. 2003. The Piratisation of Russia: Russian Reform Goes Awry. London: Routledge.

Goldman, M.I. 2008. Petrostate: Putin, Power, and the New Russia. Oxford University Press.

Gregory, P., and W. Schrettl. 2004. "Administration and Reform of the Russian Economy", In Hardt, J.P. (Ed.), Russia's Uncertain Economic Future. New York: M.E. Sharpe Inc., pp. 81-96.

Guriev, S., and A. Rachinsky. 2005. "The Role of Oligarchs in Russian Capitalism." Journal of Economic Perspectives 19: 131-150.

Hanson, P. 2009. "The Resistible Rise of State Control in the Russian Oil Industry." Eurasian Geography and Economics 50: 14-27.

Hedlund, S. 2001. "Property Without Rights: Dimensions of Russian Privatisation." Europe-Asia Studies 53: 213-237.

Hoffman, D. E. 2002. The Oligarchs: Wealth and Power in the New Russia. New York: Public Affairs.

Hoff, K., and J.E. Stiglitz. 2004. "After the Big Bang? Obstacles to the Emergence of the Rule of Law in Post-Communist Societies." The American Economic Review 94: 753763.

Ivanenko, V. 2005. “The Importance of Being Normal.” Russia in Global Affairs 4: 1-6.

Kalyuzhnova, Y., and C. Nygaard. 2008. "State Governance Evolution in Resource-Rich Transition Economies: an Application to Russia and Kazakhstan." Energy Policy 36: 1829-1842.

Kuznetsov, P. and A. Muravyev. 2001. "Ownership Concentration and Firm Performance in Russia: the Case of Blue Chips of the Stock Market." Acta Oeconomica 51: 469-488.

Lane, D. 2008. "From Chaotic to State-led Capitalism." New Political Economy 13: 177184.

Perotti, E.C., and S. Gelfer. 2001. "Red Barons or Robber Barons? Governance and Financing in Russian Financial-Industrial Groups." European Economic Review 45: 1601-1617. 
Puffer, S.M., and D.J. McCarthy. 2003. "The Emergence of Corporate Governance in Russia." Journal of World Business 38: 284-298.

Rapaczynski, A. 1996. "The Roles of the State and the Market in Establishing Property Rights." The Journal of Economic Perspectives 10: 87-103.

Robinson, N. 2002. Russia: A State of Uncertainty. London: Routledge.

Ross, C. 2004. Russian Politics Under Putin. Manchester: Manchester University Press.

Rossiaud, S., and C. Locatelli. 2009. "The Obstacles in the Way of Stabilising the Russian Oil Model." Post-Communist Economies 21: 425-438.

Shleifer, A. and R.W. Vishny. 1998. The Grabbing Hand: Government Pathologies and Their Cures. Cambridge, MA: Harvard University Press.

Smith, N. 2009. “Toxic Capitalism.” New Political Economy 3: 407:412.

Sonin, C. 2000. "Inequality, Property Rights, and Economic Growth in Transition Economies: Theory and Russian Evidence." EERC Research Network, Working Paper No. 2K/02.

Spicer, A., and W. Pyle. 2003. "Institutions and the Vicious Circle of Distrust in the Russian Household Deposit Market 1992-1999.” William Davidson Institute, Working Paper No. 588.

Sprenger, C. 2002. "Ownership and Corporate Governance in Russian Industry: a Survey." European Bank for Reconstruction and Development, Working Paper No. 70.

Stiglitz, J.E. 2002. Globalisation and Its Discontents. New York: W.W. Norton.

Thomson, W. 2002. "The Present and Future of Banking Reform", in Lane, D. (Ed.), Russian Banking Evolution, Problems and Prospects, Cheltenham: Edward Elgar, pp. 5678.

Tompson, W. 2005. "Putting Yukos in Perspective." Post-Soviet Affairs 21: 159-181.

Tompson, W. 2008. "Back to the Future? Thoughts on the Political Economy of Expanding State Ownership in Russia.” Available online http://eprints.bbk.ac.uk/509/1/Back_to_the_Future.pdf

Vidova, V. 2009. "Resource Nationalism, Bargaining and International Oil Companies: Challenges and Change in the New Millennium." New Political Economy 4: 517:534.

Woodruff, D.M. 2007. "The Expansion of State Ownership in Russia: Cause for Concern?" Development and Transition 7: 11-13. 


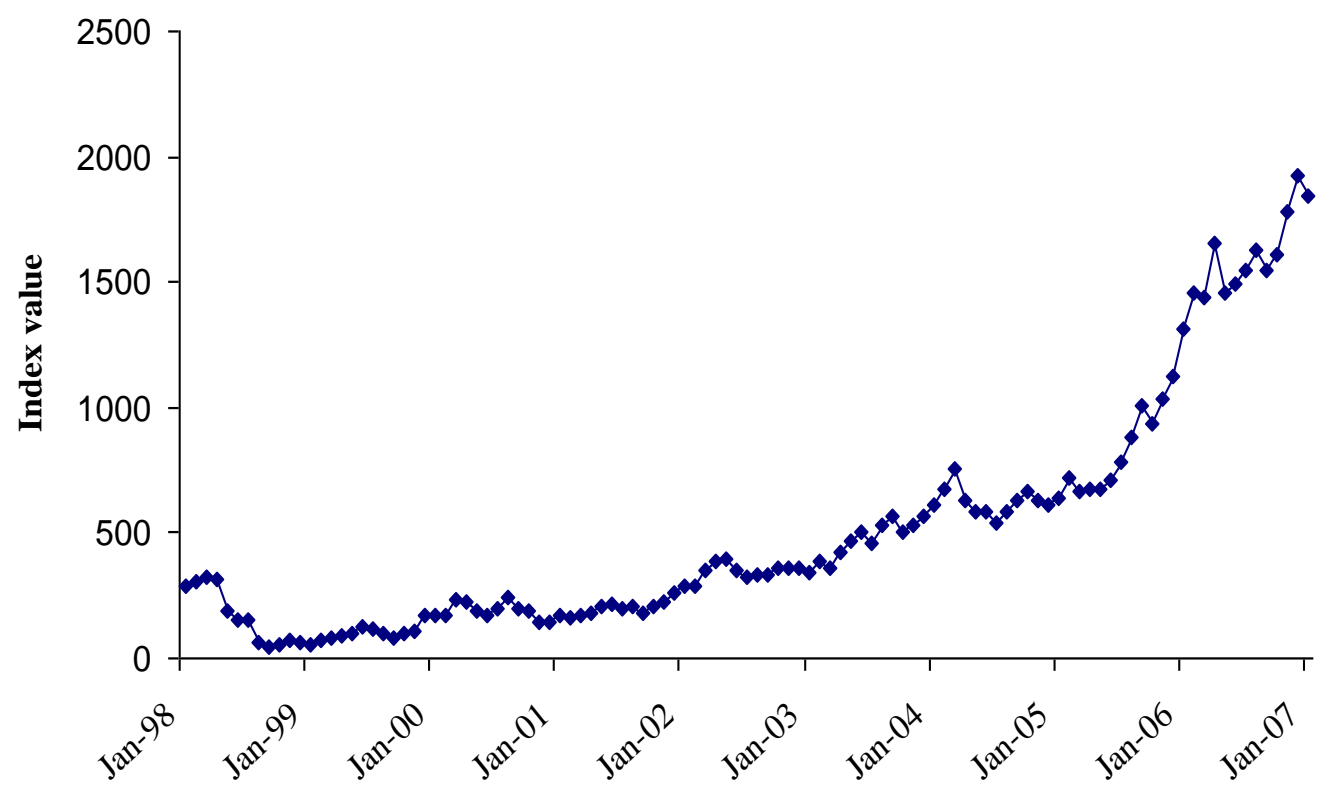

Figure 1. Performance of RTS index during 1998-2006 
Table 1. Number of firms belonging to eight industrial sectors registered on RTS during 1998-2006

\begin{tabular}{cccccccccc}
\hline Year & Manufacturing & Utility & $\begin{array}{c}\text { Metallurgy } \\
\text { \& Mining }\end{array}$ & Energy & Transport & $\begin{array}{c}\text { Communi } \\
\text { cations }\end{array}$ & $\begin{array}{c}\text { Banking } \\
\& \\
\text { Services }\end{array}$ & $\begin{array}{c}\text { Food } \\
\text { Retail }\end{array}$ & Total \\
\hline 1998 & 34 & 54 & 15 & 18 & 7 & 12 & 5 & 5 & 150 \\
1999 & 40 & 58 & 20 & 19 & 7 & 14 & 8 & 6 & 172 \\
2000 & 41 & 58 & 19 & 19 & 7 & 15 & 9 & 7 & 175 \\
2001 & 41 & 58 & 19 & 19 & 7 & 15 & 14 & 9 & 182 \\
2002 & 42 & 58 & 19 & 19 & 7 & 15 & 16 & 10 & 186 \\
2003 & 43 & 58 & 22 & 19 & 7 & 15 & 17 & 13 & 194 \\
2004 & 43 & 63 & 23 & 19 & 7 & 15 & 21 & 13 & 204 \\
2005 & 46 & 101 & 24 & 19 & 7 & 15 & 23 & 14 & 249 \\
2006 & 45 & 106 & 24 & 19 & 7 & 15 & 23 & 14 & 253 \\
\hline
\end{tabular}


Table 2. Major owners of firms trading on RTS during 1998-2006

\begin{tabular}{|c|c|c|c|c|c|c|c|c|c|}
\hline & 1998 & 1999 & 2000 & 2001 & 2002 & 2003 & 2004 & 2005 & 2006 \\
\hline State (direct/indirect) & 64 & 74 & 71 & 69 & 65 & 59 & 63 & 80 & 82 \\
\hline Regional state & 8 & 11 & 11 & 11 & 10 & 7 & 4 & 3 & 3 \\
\hline $\begin{array}{l}\text { Domestic } \\
\text { firm/financial } \\
\text { institution }\end{array}$ & 15 & 41 & 53 & 54 & 63 & 74 & 73 & 70 & 72 \\
\hline $\begin{array}{l}\text { Foreign } \\
\text { firm/financial } \\
\text { institution }\end{array}$ & 14 & 27 & 21 & 19 & 27 & 24 & 25 & 27 & 34 \\
\hline Individual & 3 & 8 & 7 & 9 & 8 & 8 & 3 & 8 & 9 \\
\hline $\begin{array}{l}\text { New state-private co- } \\
\text { ownership }\end{array}$ & 6 & 9 & 17 & 20 & 20 & 29 & 25 & 26 & 45 \\
\hline
\end{tabular}


Table 3. State-private co-ownership across eight industrial sectors during 19982006

\begin{tabular}{|c|c|c|c|c|c|c|c|c|c|}
\hline & 1998 & 1999 & 2000 & 2001 & 2002 & 2003 & 2004 & 2005 & 2006 \\
\hline Utility & $\begin{array}{c}1 \\
(2 \%)\end{array}$ & $\begin{array}{c}1 \\
(2 \%)\end{array}$ & $\begin{array}{c}4 \\
(7 \%)\end{array}$ & $\begin{array}{c}5 \\
(9 \%)\end{array}$ & $\begin{array}{c}5 \\
(9 \%)\end{array}$ & $\begin{array}{c}12 \\
(21 \%)\end{array}$ & $\begin{array}{c}10 \\
(16 \%)\end{array}$ & $\begin{array}{c}10 \\
(10 \%)\end{array}$ & $\begin{array}{c}19 \\
(18 \%)\end{array}$ \\
\hline Energy & $\begin{array}{c}1 \\
(6 \%)\end{array}$ & $\begin{array}{c}0 \\
(0 \%)\end{array}$ & $\begin{array}{c}1 \\
(5 \%)\end{array}$ & $\begin{array}{c}2 \\
(11 \%)\end{array}$ & $\begin{array}{c}2 \\
(11 \%)\end{array}$ & $\begin{array}{c}3 \\
(16 \%)\end{array}$ & $\begin{array}{c}2 \\
(11 \%)\end{array}$ & $\begin{array}{c}3 \\
(16 \%)\end{array}$ & $\begin{array}{c}3 \\
(16 \%)\end{array}$ \\
\hline $\begin{array}{l}\text { Metallurgy \& } \\
\text { Mining }\end{array}$ & $\begin{array}{c}0 \\
(0 \%)\end{array}$ & $\begin{array}{c}1 \\
(5 \%)\end{array}$ & $\begin{array}{c}1 \\
(5 \%)\end{array}$ & $\begin{array}{c}2 \\
(10 \%)\end{array}$ & $\begin{array}{c}2 \\
(10 \%)\end{array}$ & $\begin{array}{c}2 \\
(9 \%)\end{array}$ & $\begin{array}{c}3 \\
(17 \%)\end{array}$ & $\begin{array}{c}3 \\
(13 \%)\end{array}$ & $\begin{array}{c}5 \\
(21 \%)\end{array}$ \\
\hline Transport & $\begin{array}{c}2 \\
(29 \%)\end{array}$ & $\begin{array}{c}2 \\
(29 \%)\end{array}$ & $\begin{array}{c}1 \\
(14 \%)\end{array}$ & $\begin{array}{c}1 \\
(14 \%)\end{array}$ & $\begin{array}{c}1 \\
(14 \%)\end{array}$ & $\begin{array}{c}1 \\
(14 \%)\end{array}$ & $\begin{array}{c}0 \\
(0 \%)\end{array}$ & $\begin{array}{c}0 \\
(0 \%)\end{array}$ & $\begin{array}{c}1 \\
(14 \%)\end{array}$ \\
\hline Manufacturing & $\begin{array}{c}0 \\
(0 \%)\end{array}$ & $\begin{array}{c}3 \\
(8 \%)\end{array}$ & $\begin{array}{c}7 \\
(17 \%)\end{array}$ & $\begin{array}{c}7 \\
(17 \%)\end{array}$ & $\begin{array}{c}7 \\
(17 \%)\end{array}$ & $\begin{array}{c}8 \\
(19 \%)\end{array}$ & $\begin{array}{c}7 \\
(16 \%)\end{array}$ & $\begin{array}{c}7 \\
(15 \%)\end{array}$ & $\begin{array}{c}14 \\
(30 \%)\end{array}$ \\
\hline Communications & $\begin{array}{c}1 \\
(8 \%)\end{array}$ & $\begin{array}{c}1 \\
(7 \%)\end{array}$ & $\begin{array}{c}1 \\
(7 \%)\end{array}$ & $\begin{array}{c}1 \\
(7 \%)\end{array}$ & $\begin{array}{c}1 \\
(7 \%)\end{array}$ & $\begin{array}{c}1 \\
(7 \%)\end{array}$ & $\begin{array}{c}1 \\
(7 \%)\end{array}$ & $\begin{array}{c}1 \\
(7 \%)\end{array}$ & $\begin{array}{c}1 \\
(7 \%)\end{array}$ \\
\hline $\begin{array}{l}\text { Banking \& } \\
\text { Services }\end{array}$ & $\begin{array}{c}0 \\
(0 \%)\end{array}$ & $\begin{array}{c}0 \\
(0 \%)\end{array}$ & $\begin{array}{c}1 \\
(11 \%)\end{array}$ & $\begin{array}{c}1 \\
(7 \%)\end{array}$ & $\begin{array}{c}1 \\
(6 \%)\end{array}$ & $\begin{array}{c}1 \\
(6 \%)\end{array}$ & $\begin{array}{c}0 \\
(0 \%)\end{array}$ & $\begin{array}{c}1 \\
(4 \%)\end{array}$ & $\begin{array}{c}1 \\
(4 \%)\end{array}$ \\
\hline Food \& Retail & $\begin{array}{c}1 \\
(20 \%)\end{array}$ & $\begin{array}{c}1 \\
(17 \%)\end{array}$ & $\begin{array}{c}1 \\
(14 \%)\end{array}$ & $\begin{array}{c}1 \\
(11 \%)\end{array}$ & $\begin{array}{c}1 \\
(10 \%)\end{array}$ & $\begin{array}{c}1 \\
(8 \%)\end{array}$ & $\begin{array}{c}2 \\
(15 \%)\end{array}$ & $\begin{array}{c}1 \\
(7 \%)\end{array}$ & $\begin{array}{c}1 \\
(7 \%)\end{array}$ \\
\hline Total & 6 & 9 & 17 & 20 & 20 & 29 & 25 & 26 & 45 \\
\hline
\end{tabular}


i The policy was supported by relatively improved legal infrastructure, which reduced the costs of transacting across the market

ii The overall number of companies reported in the table is 253 . However, it was possible to obtain accurate ownership information on 245 firms

iii Only 1 "widely held" corporation was identified, where the principal shareholder owned less than 5 percent of firm's capital

${ }^{\text {iv }}$ If the firm is partially owned by the state, it falls into the state-private co-ownership category

${ }^{v}$ The percentage figure denotes the proportion of state-private owned enterprises relative to the overall number of firms in this industry

${ }^{\mathrm{vi}}$ Lessons learned form the privatisation process in the 1990s

vii The government also aims to protect its extensive subsidies, which can be appropriated by insider managers and lower level bureaucrats under a weak legal system 